model (DE BLAEY and VAN DER GRAAFF 1977).

The hard and soft tablets tested did not meet the requirements under which the cube root law applies. The shape of the tablets in the models was retained fairly well after a dissolution of about $50 \%$ of the mass. With proceeding dissolution, however, a visible change in shape of the tablets was observed in all models, except the paddle design. In the sandwich model the tablets became oval (the long axis in a direct line with the impeller axis) during dissolution, as could be expected from the flow patterns in a stirrer/vessel design (LAGAS and LERK 1977). The tablet tumbled out of the sandwich holder after a weight loss of about $94 \%$.

Figure 5 shows the mean of the deviant behaviour of each dissolution profile with respect to its regression line for a dissolution up to $50 \%$ of mass, both calculated according the cube root and the square root respectively, expressed as a percentage of the original tablet weight. The data presented in this way permit tracing of a systematically deviant behaviour from both kinetic expressions applied. Except for the paddle model, a tendency to a better description of the dissolution kinetics in the models for the hard tablets by the square root and the soft tablets by the cube root expression, is present. The change in systematically deviant behaviour of the plots in relation to its regression lines from one type of tablet to the other is most obvious for the erosive basket design. For the paddle model, on the contrary, no change is perceptible.

The results presented indicate, that the four dissolution apparatus tested, can roughly be grouped into the non- or at most slightly erosive paddle and sandwich designs, and the moderate to highly erosive disintegration and rotating basket models. Moreover it is shown, that the release profiles are strongly affected by the phenomenon of erosion during dissolution.

\section{REFERENCES}

Blaey, C.J. De, and h. van Der GraAfF (1977) J. Pharm. Sci. 66, 1696.

CARSTENSEN, J.T., J.L. WRIGHT, K. BLESSEL and J. SHERIDAN (i978) J. Pharm. Sci. 67, 982.

CARSTENSEN, J.T., R. KOTHARI, V.K. PRASAD and J. SHERIDAN (1980) J. Pharm. Sci. 69, 290.

gumma, A., H. hess and R.A. Ramsay (1971) Pharm. Ind. $33,29 \mathrm{I}$.

JONKMAN, J.H.G., R. SCHOENMAKER, N. GRIMBERG and R.A. DE ZEEUW (I98I) Intern. J. Pharm. 8, I 53.

LAGAS, M., and C.F. LERK (I977) Pharm Weekbl. II2, 845 .

MÖlleR, H., and D. STEINBaCH (1979) Pharm. Zig. I24, I 207.

MÖLLER, H., S.L. ALI and D. STEINBACH (1980) Intern. J. Pharm. 7, I57.

Parroti, E. L., D.e. WURSTer and T. Higuchi (1955) J. Am. Pharm. Assoc., Sci. Ed. 44, 269.

STEINBACH, D., and H. MÖLLER (I977a) Pharm. Ztg. I22, 507; Ibidem (1977b) 122, 2067.

TINGSTAD, J., E. GROPPER, L. LACHMAN and E. SHAMI (I973) J. Pharm. Sci. 62, 293.

Received April I982.

Accepted for publication September 1982.

\title{
Drug release from non-aqueous suspensions. I. Release of phenobarbital and phenobarbital sodium from paraffin suspensions. Erratum
}

\section{J.G. FOKKENS AND C.J. DE BLAEY}

In the paper 'Drug release from non-aqueous suspensions. I. Release of phenobarbital and phenobarbital sodium from paraffin suspensions', published in Pharm. Weekbl. Sci. Ed. (1982) 4, I 17-1 2 I, the two photographs forming Figure 4 (page I 20) were printed upside down. The dark part of the photographs, indicating the paraffin layer, should have appeared on top. 